\title{
Editorial preface
}

\author{
R. L. Hall ${ }^{1}$
}

Published online: 6 September 2019

(c) Springer Nature B.V. 2019

Our journal has always been open to articles from both the analytic and the continental philosophical perspectives. This issue demonstrates our welcome to the continental approach.

In the first article, Darren Dahl discuses religious diversity and universality from the perspective of the phenomenology of religion of Paul Ricoeur. A key figure in his discussion is Ricoeur's concept of "linguistic hospitality". This concept rejects phenomenological approaches that search for the universal meaning of religion by treating religions as simply examples that reveal a common universal structure. Such abstracting approaches that focus on the structural elements of religion in general miss the importance of the origins of concrete historical religious traditions. The search to find the meaning of religion can easily blind us to the rich diversity of religions. For example, even though we can no longer hear the words of the prophets, we must begin our phenomenology of the biblical prophetic tradition at the beginning, that is, by trying to hear their words as they were first said, that is, by searching for their traces in the temporal and rich cultural settings where their words were spoken. We must extend our linguistic hospitality to such originating words; we must take them in no matter how strange they may seem. These original words have left traces and the task of the phenomenology of religion ought to be to follow them, to retrace them, to hear them again. Otherwise, the phenomenology of religion will become static and totalizing. But this does not mean that we must abandon the search for the universal, only that a felicitous search for it must begin at the beginning, that is, with origins. This may not mean that the particular is higher than the universal, as Kierkegaard once remarked, but it surely means that the particular is prior to the universal. The phenomenology of religion must begin its search for what religion is with religions; phenomenology must begin with phenomena.

Daniel Herskowitz's article is about Martin's (Buber) critique of Martin (Heidegger). He begins by noting their common interest in the poetry of Hölderlin and by noting as well critically important differences in their interpretations of Hölderlin's understanding of the relation between language and being. More importantly, Herskowitz also sees that Heidegger, unlike Sartre, and hence like Buber, is no atheist.

\section{R. L. Hall}

ronhall@stetson.edu

1 Department of Philosophy, Stetson University, Deland, FL 32723, USA 
Indeed, he makes a point of the fact that Buber recognized that Heidegger was interested in providing a new post-Nietzschean conception of the divine and especially a new concept of the relationship between human existence and the divine. And yet despite this commonality, Buber rejects what he takes to be Heidegger's' mistake of thinking of the human-divine relationship in terms of magic. The point of the article is to argue that Buber was wrong to think that Heidegger's notion of the "return of the gods" is also a return of religion to magic. For Buber, this is a mistake since the divine-human relation is dialogical and magic implies a non-relation of manipulation and control between the human and the divine. But as Herskowitz argues, due consideration to Heidegger's critique of technology, and its rejection of modern tendencies toward objectification, manipulation, and control, shows that he and Buber are in more agreement than Buber thinks.

What would an issue devoted to the continental approach to the philosophy of religion be without an article on Nietzsche? In our last article, Stuart Jesson fills this gap. His focus is on Nietzsche's famous call to affirm our existence in the face of the death of God. Some have remarked that this call to affirmation is connected to Nietzsche's doctrine of eternal return. According to one interpretation, his doctrine presents us with a test to see who has truly embraced his call to affirmation: those who have succeed in achieving this embrace are those who would welcome the thought of living their lives again (and again and again). Jesson claims that Simone Weil's idea of "consent to necessity" has much in common with this Nietzschean call to affirmation. An important element of this overlap is the fact that both urge an affirmation of our existence in the face of its intrinsic suffering and threats of meaninglessness. It may not be as clearly noted, however, but it is also true that both hold that this call to affirmation must be made in the absence of any existential teleology. Clearly, affirmation comes easier if we think that in the end all will be OK. But can we embrace a full-throated affirmation of our existence if we do not have confidence that in the end the whole of it will be shown to be worth our affirmation? Jesson argues that both Nietzsche and Weil think such a confidence is impossible to attain. Without this, the call to affirmation is even more starkly challenging. Yet this is precisely the challenge that Nietzsche and Weil pose.

Publisher's Note Springer Nature remains neutral with regard to jurisdictional claims in published maps and institutional affiliations. 